\title{
Modeling the Influence of Certain Weather Parameters on Oil Palm Production in Peninsular Malaysia
}

\author{
Ahmed Abubakar ${ }^{1 *}$, Mohd Yusoff Ishak ${ }^{2}$, Md Kamal Uddin ${ }^{3}$, Zakiah Ponrahono ${ }^{4}$ and Murtala Muhammad Uba ${ }^{5}$ \\ ${ }^{1}$ Faculty of Forestry and Environment, Universiti Putra Malaysia, 43400 Serdang, Selangor, Malaysia; abuba- \\ kar8550483@gmail.com \\ ${ }^{2}$ Faculty of Forestry and Environment, Universiti Putra Malaysia, 43400 Serdang, Selangor, Malaysia \\ m_yusoff@upm.edu.my \\ ${ }^{3}$ Faculty of Forestry and Environment, Universiti Putra Malaysia, 43400 Serdang, Selangor, Malaysia \\ ${ }^{4}$ Faculty of Agriculture University Putra Malaysia, 43400 Serdang, Selangor, Malaysia, Email: mkud- \\ din@upm.edu.my \\ $\underline{5 \text { Department of Geography, Bayero University, Kano, Nigeria }}$
}

* Correspondence: e-mail; abubakar8550483@gmail.com Tel.: +601120755790

Abstract: Oil palm is one of the most important crops in Malaysia. Lately, the production of oil palm has been reduced due to a variety of factors, including the weather and climate. Temperature, wind speed, relative humidity, sunshine, and rainfall distribution all have an impact on palm tree growth and development, which in turn has an impact on oil palm production. This paper aims to investigate the effects of some weather elements (temperature, wind speed, relative humidity, sunshine, and rainfall) on oil palm production in Peninsular Malaysia. Data were analyzed using the Statistical Package for Social Sciences (SPSS 20.0 version), with descriptive statistics, and multiple linear regression (MLR). The MLR model determined the strength of the relationship between oil palm yield (dependent variable) and the changing variables of temperature, sunshine, wind speed, relative humidity, and rainfall (independent variables). The findings revealed that temperature, wind speed, relative humidity, sunshine, and rainfall have a low impact on oil palm production and yield turnover. The R2 value of 0.202 shows that the independent variables explained only $20.2 \%$ of the fluctuation in palm oil production. The study recommends working within an integrated approach involving scientific research, planting, improving variety, improving regional academic leadership, and engaging private and public stakeholders, emphasized collaborative efforts with researchers in consumer countries, and strengthening the capacity of growers to best agroecological practices.

Keywords: oil palm; modeling; climate; temperature; rainfall, sunshine, wind, humidity

\section{Introduction}

The oil palm (Elaeis guineensis) is native to West Africa, where it can be found between Angola and Gambia [1-2]. Oil palm requires at least 2,000 $\mathrm{mm}$ of rainfall distributed evenly throughout the year, which equates to about $167 \mathrm{~mm}$ per month [3-4]. Furthermore, minimum temperatures should be between 22 and $24^{\circ} \mathrm{C}$ and maximum temperatures should be between 29 and $33^{\circ} \mathrm{C}$, with relative humidity greater than $85 \%$ [5]. The solar radiation level should be at least 16 or $17 \mathrm{MJ} \mathrm{m}^{-1} \mathrm{~d}^{-1}[6]$. 
Oil palm was first planted in South-east Asia in 1848 at the Bogor Botanical Garden in Indonesia [7]. In the 1870s, Malaysia received its first batch of oil palm from the Royal Botanical Garden, United Kigdom. The first commercial oil palm plantation in Malaysia was established in 1917 at Tennamaran Estate, Selangor [8]. In total, there are eleven important oil palm producing countries, including Indonesia, Malaysia, Nigeria, the Democratic Republic of the Congo, the Ivory Coast, Brazil, Colombia, Costa Rica, and Ecuador [9-10].

Indonesia and Malaysia produce approximately $83 \%$ of the world's palm oil, which makes a significant contribution to their economies [11-12]. Malaysian palm oil exports contribute to $45 \%$ of the global oil palm needs [13]. The economy of Malaysia benefits greatly from the financial returns from the sale of palm oil [14]. Crude palm oil is used in cooking, detergent, soap, plastics, oleo-chemicals, cosmetics, pharmaceuticals, biodiesel, etc [15-16-17]. Large-scale oil palm cultivation has made a tremendous transformation in tropical regions, people's lives, and the profits of palm oil companies [18]. The crop's high output, ease of establishment, and low costs make it very profitable and the most economically efficient oil crop [19-20].

Tropical countries, in particular, are negatively affected by climate change, which also has a detrimental impact on oil palm agronomy, whereas the cultivation of oil palm increases the impact of climate change [21]. Climate has changed over centuries, and will undoubtedly continue to change in the future, and the change will affect crop production globally [22-23]. Although awareness of the effects of climate change on crop production and disease has grown [24], the effects on tropical crops are less understood [25]. As noted by Paterson [26] climate change threatens the sustainability of oil palm production. Various factors influence oil palm production, including planting material, cultivation management, soil and the environment, or climate, usually rainfall, temperature, relative humidity, wind and solar radiation [27].

Weather and climate are prominent drivers that influences oil palm production systems. In spite advances in technology and crop science, a fluctuation in oil palm yield had been noticed recently [28-29]. Variation in the climatic variables might had been responsible for the substantially changes. The distribution of rainfall affects the growth and development of palm trees, which in turn affects oil palm production [30]. Excessive rainfall also harms the fresh fruit bunch (FFB), stifles harvest activity, and causes flooding. Oil palm yield is limited by the length of the annual dry season, so areas with consistent high rainfall throughout the year, such as parts of Southeast Asia, have particularly high yields [31-32-33-34-35-36]. Previous studies have stated that an increase in water deficit of $100 \mathrm{~mm}$ in one year can decrease production by $8-10 \%$ in the first year after that and by $3-4 \%$ in the second year [37-38]. Corley and Tinker [39] explained in more detail that a $100 \mathrm{~mm}$ water deficit could have an impact on FFB production in the flowering phase, namely floral initiation (1-3\% yield loss per $100 \mathrm{~mm}$ water deficit), sex determination (3$4 \%$ yield loss), and floral abortion (8-10\% yield loss).

When temperature rises by $1-4^{0} \mathrm{C}$, oil palm cultivation is expected to decline by $10-40 \%$ in Malaysia [40]. Warmer temperatures will also cause dry periods to increase, which will cause a loss of oil palm yield. As temperatures become warmer, soil water 
evaporates more quickly, so the impacts of dry periods become more intense [41]. The average monthly temperature eight months prior to harvest of $27.83^{\circ} \mathrm{C}$ led to low FFB yield [42-43]. Wind speed is found to have an impact on oil palm cultivation [44]. The total sunshine hours is not the only site-specific factor for oil palm production [45]. The simultaneous availability of soil moisture also plays an important role in determining the effective sunshine hour for maximising FFB yield [46]. Direct sunlight boosts palm productivity. The lower incidence of cloud cover over much of Southeast Asia is thought to be one of the reasons why oil palm yields are mostly higher than in West Africa [4748]. Photoperiod response regulates oil palm flowering [49]. In 2014, 2015, and 2016, the palm oil yield dropped by $0.3 \%, 1.9 \%$, and $17 \%$, respectively, to $3.84,3.78$, and 3.21 tha${ }^{1}$, compared to the previous year's record of 3.84, 3.78, and $3.21 \mathrm{t} \mathrm{ha}^{-1}$. The decrease in palm oil yield has been attributed to a decrease in FFB yield in recent years [50-51].

With oil palm producing accounting fthe highest agricultural yield in Malaysia, research into the effects of climatic element on oil palm cultivation does not receive the same level of attention as that cereal crops. As a result, this study seeks to investigate the most recent trends of climatic elements in Peninsualr Malaysia, as well as the effects of these climatic elements on oil palm cultivation. The study also makes some recommendations to improve oil palm cultivation in Malaysia.

\section{Materials and Methods}

\subsection{The Study Area}

Peninsular Malaysia is geographically located on latitude $1^{0}$ and $7^{0}$ north and between $99^{\circ}$ and $105^{\circ}$ east. The region occupied a total land area of $132,000 \mathrm{~km}^{2}$ and mainly composed the highlands, floodplains, and coastal zones. overall, the Peninsular, has a warm and humid tropical climate throughout the year, with temperature ranges from $25^{\circ} \mathrm{C}$ to $32^{\circ} \mathrm{C}$. The region is characterized by two monsoon seasons: the southwest monsoon from May to September and the northeast monsoon from November to March, which is associated with high rainfall [52-53]. The region records annual rainfall of 2000$4000 \mathrm{~mm}$ [54]

\subsubsection{Method}

Secondary data was used for the purpose of this study. Data on oil palm yield in Malaysia between 1990-2020 was obtained from the Malaysian Palm Oil Board (MPOB). Climate historical data, particularly average annual temperature and rainfall, sunshine, relative humidity and wind speed were also downloaded from the climate-knowledge portal of the World Bank, and National Aeronautics and Space Administration (NASA) in July, 2021.

\subsubsection{Data Analysis}

Multiple linear regression, an extension of simple linear regression used where there is more than one independent variable was employed by the study. The model was adopted because the independent variable was interval scale. The independent variables should be mostly interval or scale level variables, but multiple regression can also have dichotomous independent variables called dummy variables. In this study, the independent variables refer to relative humidity $(\%)$, wind speed $(\mathrm{m} / \mathrm{s})$, mean rainfall 
$(\mathrm{mm})$, mean temperature $\left({ }^{\circ} \mathrm{C}\right)$ and sunshine/solar radiation $\left(\mathrm{MJ} / \mathrm{m}^{\wedge} 2 /\right.$ day $)$. The dependent variable is the yield of oil palm. In regression analysis, assumptions need to be considered as the samples are normally distributed and uncorrelated with the other variables. There is a linear relationship between the independent variables and the dependent variable and no multicollinearity issues. As a result, this study analyzed bivariate correlation to examine the linear relationship and continued to examine the Variance Inflation Factor (VIF) and tolerance to confirm the presence of multicollinearity. The values of tolerance must be less than 5 and tolerance values greater than 0.2 [55].

The multiple linear regression equation is follow as:

$$
\mathrm{Y}=\beta_{0}+\mathrm{B}_{1} \mathrm{X}_{1}+\mathrm{B}_{2} \mathrm{X}_{2}+\ldots . \mathrm{Bn} \mathrm{Xn}+\varepsilon
$$

The yield of oil palm are influenced by relative humidity, wind speed, mean rainfall, mean temp and sunshine/solar radiation. For multiple linear regression, the coefficient is estimated similar to simple linear regression. For this case of study, the proposed model would be:

Yield tonne $(\mathrm{Y})=\beta_{0}+\mathrm{B}_{1}$ RelativeH $+\mathrm{B}_{2}$ WindS $+\mathrm{B}_{3}$ Rainfall $+\mathrm{B}_{4}$ Temp $+\mathrm{B}_{3}$ SolarR $+\varepsilon$

\section{Results and Discussion}

The mean yield was 18.719 tonne per hectare, $87.120 \%$ of relative humidity, and the mean wind speed was $0.502 \mathrm{~m} / \mathrm{s}$. In addition, the mean rainfall was $243.967 \mathrm{~mm}, 26.010$ mean temperature, and 35.659 was the mean of solar radiation. The analysis indicates the histogram was symmetrical, explained to the normal distribution, and met the following regression analysis assumption.

Table 1: Descriptive Analysis

\begin{tabular}{|c|c|c|c|c|}
\hline Variables & Mean & Std. Deviation & Skewness & Kurtosis \\
\hline Yield tonne/hectare & 18.719 & 1.391 & 0.612 & 1.195 \\
\hline Relative Humidity (\%) & 87.120 & 1.429 & -2.953 & 1.076 \\
\hline Wind Speed (M/S) & 0.502 & 0.020 & 0.022 & -0.182 \\
\hline Mean rainfall (mm) & 243.967 & 48.922 & -2.564 & 1.401 \\
\hline Mean Temp (0C) & 26.010 & 1.170 & 4.043 & 1.193 \\
\hline $\begin{array}{l}\text { Sunshine/Solar } \\
\left(\mathrm{MJ} / \mathrm{m}^{\wedge} 2 / \text { day }\right)\end{array}$ & 35.659 & 0.784 & -2.454 & 4.541 \\
\hline
\end{tabular}

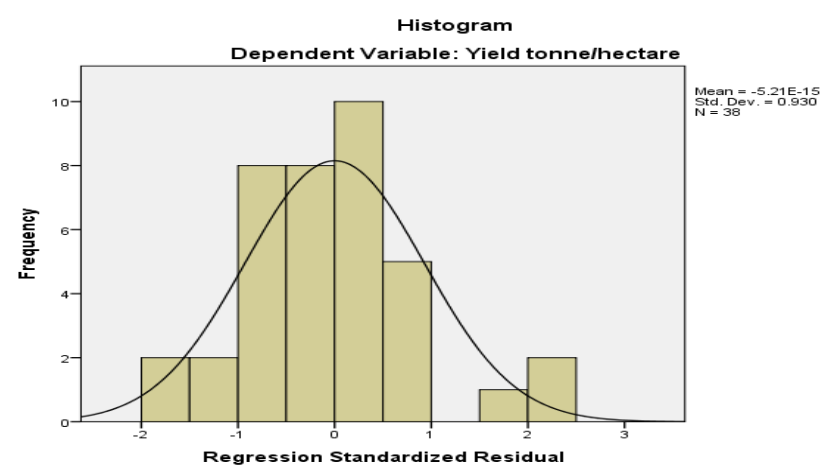

Figure 1. Regression standardize residual. 
The linear relationship conducted using bivariate correlation. A linear relationship of sunshine/solar radiation has a significant and inverse relationship with temperature from the analysis. In addition, the relative humidity, wind speed, rainfall, temperature, and sunshine were not significant to yield.

Table 2. Correlation Analysis

\begin{tabular}{|c|c|c|c|c|c|c|c|c|}
\hline Variables & Mean & Std & 1 & 2 & 3 & 4 & 5 & 6 \\
\hline $\begin{array}{l}\text { 1. Yield } \\
\text { tonne/hectare }\end{array}$ & 18.719 & 1.391 & 1.000 & & & & & \\
\hline Relative & 87.120 & 1.429 & .275 & 1.000 & & & & \\
\hline Humidity & & & & & & & & \\
\hline 3. Wind Speed & 0.502 & 0.020 & .030 & -.331 & 1.000 & & & \\
\hline 4. Mean rainfall & 243.967 & 48.922 & .123 & .208 & -.142 & 1.000 & & \\
\hline 5. Mean Temp & 26.010 & 1.170 & -.381 & -.112 & -.213 & -.278 & 1.000 & \\
\hline $\begin{array}{l}\text { 6. Sunshine/Solar } \\
\text { radiation }\end{array}$ & 35.659 & 0.784 & .390 & .375 & .075 & .326 & $-.827^{*}$ & 1.000 \\
\hline
\end{tabular}

*Significance level at 0.05

Table 3 revealed that if the combined effect of relative humidity, wind speed, mean rainfall, mean temp and sunshine/solar radiation regressed on the oil palm yield of the sample under study, an F-value of 1.618 was obtained and at $\mathrm{df}$ of 5 and 32 the $\mathrm{p}>.05$. Based on the result obtained the climatic parameter did not contribute significantly to the change to yield variation. Further, the result explained by the combined effect of relative humidity, wind speed, mean rainfall, mean temp and sunshine/solar radiation do not significantly influence the yield of oil palm.

Table 3. ANOVA Analysis

\begin{tabular}{|c|c|c|c|c|c|c|}
\hline \multicolumn{7}{|c|}{ ANOVA } \\
\hline & & Sum of & & Mean & & \\
\hline Model & & Squares & $\mathrm{df}$ & Square & $\mathrm{F}$ & Sig. \\
\hline \multirow[t]{3}{*}{1} & Regression & 14.438 & 5 & 2.888 & 1.618 & .184 \\
\hline & Residual & 57.124 & 32 & 1.785 & & \\
\hline & Total & 71.562 & 37 & & & \\
\hline
\end{tabular}

The multiple linear regression model obtained as follows:

Yield of oil palm $(y)=4.553+0.235$ Relative $H+2.451$ WindS -0.001 Rainfall -0.380 temp + 0.071SolarR

From the model, it is evident that the relative humidity, wind speed, mean rainfall, mean temperature and sunshine/solar radiation has a low impact on the yield of oil palm. The $\mathrm{R}^{2}$ value of 0.202 indicates that only $20.2 \%$ of the variation in the oil palm yield is explained by the independent variables. This indicates that there are other variables besides relative humidity, wind speed, mean rainfall, mean temp and sunshine/solar radiation that 
influence the yield of oil palm such as farm management, soil characteritics, type of seed among others. This is consistent with study conducted at various locations in Malaysia. Shafiq [56] found that climatic elements has less impact on oil palm production and determination of Fresh Fruit Bunch yield.

Table 4. Model Summary

\begin{tabular}{|c|c|c|c|c|c|c|c|c|c|c|}
\hline \multicolumn{11}{|c|}{ Model Summary } \\
\hline & & & & & \multirow{2}{*}{\multicolumn{5}{|c|}{ Change Statistics }} & Durbin- \\
\hline & & & & Std. & & & & & & Watson \\
\hline & & $\mathrm{R}$ & Adjusted & $\begin{array}{c}\text { Error of } \\
\text { the }\end{array}$ & $\begin{array}{c}\mathrm{R} \\
\text { Square }\end{array}$ & $\mathrm{F}$ & & & Sig. F & \\
\hline Model & $\mathrm{R}$ & Square & R Square & Estimate & Change & Change & df1 & $\mathrm{df} 2$ & Change & \\
\hline 1 & $.449^{a}$ & .202 & .077 & 1.33609 & .202 & 1.618 & 5 & 32 & .184 & 1.755 \\
\hline
\end{tabular}

a. Predictors: (Constant), Sunshine/Solar radiation $\left(\mathrm{MJ} / \mathrm{m}^{\wedge} 2 /\right.$ day), Wind Speed (M/S), Mean rainfall (mm), Relative Humidity (\%), Mean Temp (0C)

b. Dependent Variable: Yield tonne/hectare

Based on the result in Table 5, all the values are greater than 0.05, therefore this study fail to reject the null hypothesis and conclude that it is not statistically significant. The Variance Inflation Factor (VIF) of relative humidity (1.522), wind speed (1.241), mean rainfall (1.164), mean temp (3.801) and sunshine/solar radiation (4.297) were less than 5. For the tolerance value relative humidity (0.657), wind speed (0.806), mean rainfall (0.859), mean temp (0.263) and sunshine/solar radiation (0.233) were greater than 0.2 . From the analysis, the result confirmed there no issues on multicollinearity.

Table 5: Coefficient

\begin{tabular}{|c|c|c|c|c|c|c|c|}
\hline & \multicolumn{2}{|c|}{$\begin{array}{c}\text { Unstandardized } \\
\text { Coefficients }\end{array}$} & \multirow{2}{*}{$\begin{array}{l}\text { Standardized } \\
\text { Coefficients } \\
\text { Beta }\end{array}$} & \multirow[t]{2}{*}{$\mathrm{t}$} & \multirow[t]{2}{*}{ Sig. } & \multicolumn{2}{|c|}{ Collinearity Statistics } \\
\hline & B & $\begin{array}{l}\text { Std. } \\
\text { Error }\end{array}$ & & & & Tolerance & VIF \\
\hline (Constant) & 4.553 & 28.432 & & .160 & .874 & & \\
\hline Relative & .235 & .190 & .241 & 1.238 & .225 & .657 & 1.522 \\
\hline Humidity & & & & & & & \\
\hline Wind Speed & 2.451 & 12.112 & .036 & .202 & .841 & .806 & 1.241 \\
\hline Mean rainfall & -.001 & .005 & -.024 & -.142 & .888 & .859 & 1.164 \\
\hline Mean Temp & -.380 & .366 & -.320 & -1.038 & .307 & .263 & 3.801 \\
\hline $\begin{array}{l}\text { Sunshine/Solar } \\
\text { radiation }\end{array}$ & .071 & .581 & .040 & .122 & .904 & .233 & 4.297 \\
\hline
\end{tabular}




\title{
5. Conclusions
}

The study conclude that climatic elements are had no significant effect in oil palm production. The mode indicating that $20.2 \%$ of the variability in monthly oil palm yield was represented by the regression equation. Future research will most likely include the delineation of climatic regions using statistical analysis of Malaysia's monthly grided data set using various climatic indices. It will be useful to further explore the relationship between oil palm yield, climatic and cultural factors aside. This will give the oil palm growers insight into the agricultural practices suitable for oil palm production.

\begin{abstract}
Author Contributions: Conceptualization, Ahmed A. and Mohd Y.I.; methodology, Ahmed A.; software, Ahmed A.; Murtala Muhammad Uba.; validation, Mohd Y.I.; Md Kamal Uddin., and Zakiah Porahono.; formal analysis, Ahmed A.; investigation, Ahmed A.; resources, Ahmed A.; data curation, Ahmed A.; writing-original draft preparation, Ahmed A..; writing-review and editing, Mohd Y.I.; Murtala Muhammad Uba.; visualization, Zakiah Ponrahono.; supervision, Muhd Y.I. Md Kamal Uddin.; project administration, Mohd Y.I.; funding acquisition, Ahmed A.; All authors have read and agreed to the published version of the manuscript.
\end{abstract}

Funding: This research was funded by Tertiary Education Trust Fund, Nigeria (TETFUND), grant number “TETF/ES/UNIV/JIGAWA STATE/TSAS/2019" and "The APC was funded by “Tertiary Education Trust Fund Nigeria (TETFUND)".

Data Availability Statement: The data presented in this study are available on request from the corresponding author. The data are not publicly available due to [the data generated from different sources].

Acknowledgments: This study wish to acknowledge the funding support from tertiary education trust fund, Nigeria (TETFUND) and Dr. Mohd Y.I for providing necessary documents and guidance toward achieving this study.

Conflicts of Interest: The authors declare no conflict of interest.

\section{References}

[1] Paterson, R. R. M.; Sariah, M.; Lima, N. How will climate change affect oil palm fungal diseases? Crop Prot. 2013, 46, 113-120.

[2] Nambiappan, B.; Ismail, A.; Hashim, N.; Ismail, N.; Shahari, D.N.; Idris, N.A.N.; Omar, N.; Salleh, K.M.; Hassan, N.A.M.; Kushairi, A. Malaysia: 100 years of resilient palm oil economic performance. J. Oil Palm Res. 2018, 30:13-25.

[3] Oettli, P.; Behera, S.K.; Yamagata, T. Climate based predictability of oil palm tree yield in Malaysia. Sci. Rep. 2018, 8:1-13.

[4] Ambar Suharyanti, N.; Mizuno, K.; Sodri, A. The effect of water deficit on inflorescence period at palm oil productivity on peatland. E3S Web of Conferences, 2020 211, 2-11.

[5] Oettli, P.; Behera, S.K.; Yamagata, T. Climate based predictability of oil palm tree yield in Malaysia. Sci. Rep. 2018, 8:1-13.

[6] Oettli, P.; Behera, S.K.; Yamagata, T. Climate based predictability of oil palm tree yield in Malaysia. Sci Rep, 2018, 8,1-13.

[7] Nambiappan, B.; Ismail, A.; Hashim, N.; Ismail, N.; Shahari, D.N.; Idris, N.A.N.; Omar, N.; Salleh, K.M.; Hassan, N.A.M.; Kushairi, A. Malaysia: 100 years of resilient palm oil economic performance. J. Oil Palm Res. 2018, 30,13-25.

[8] Nambiappan, B.; Ismail, A.; Hashim, N.; Ismail, N.; Shahari, D.N.; Idris, N.A.N.; Omar, N.; Salleh, K.M.; Hassan, N.A.M.; Kushairi, A. Malaysia: 100 years of resilient palm oil economic performance. J. Oil Palm Res. 2018, 30,13-25.

[9] Paterson, R. R. M.; Sariah, M.; Lima, N. How will climate change affect oil palm fungal diseases? Crop Prot. 2013, 46, 113-120.

[10] Ahmed, A.; Mohd, Y.I.; Abdullah, A.M. Oil palm in the face of climate change: A review of recommendations. International Conference on Civil and Environmental Engineering. Universiti Perlis. IOP Conf. Series: Environ. Earth Sci. 2021, 646, 1-10. 
[11] Shanmuganathan, S.; Narayanan, A; Mohamed, M.; Ibrahim, R.; Khalid, H. A hybrid approach to modelling the climate change effects on Malaysia's oil palm yield at the regional scale. Adv. Intell. Syst. Comput. 2014, 287, 335-346.

[12] Paterson, R. R. M.; Lima, N. Climate change affecting oil palm agronomy, and oil palm cultivation increasing climate change, require amelioration. Ecol. Evol. 2018, 8, 452-461

[12] Paterson, R. R. M.; Lima, N. Climate change affecting oil palm agronomy, and oil palm cultivation increasing climate change, require amelioration. Ecol.Evol. 2018, 8, 452-461

[13] Paterson, R. R. M.; Lima, N. Climate change affecting oil palm agronomy, and oil palm cultivation increasing climate change, require amelioration. Ecol.Evol. 2018, 8, 452-461

[14] Tang, K. H. D.; Al Qahtani, H. M. S. Sustainability of oil palm plantations in Malaysia. Environ. Dev. Sustain. 2020, 22, 4999-5023.

[15] Paterson, R.R.M.; Moen, S.; Lima, N. The feasibility of producing oil palm with altered lignin content to control ganoderma disease. J. Phytopathol. 2009, 157, 649-656.

[16] Paterson, R. R. M.; Lima, N. Climate change affecting oil palm agronomy, and oil palm cultivation increasing climate change, require amelioration. Ecol. Evol. 2018, 8, 452-461

[17] Ahmed, A.; Mohd, Y.I.; Abdullah, A.M. Oil palm in the face of climate change: A review of recommendations. International Conference on Civil and Environmental Engineering. IOP Conf. Series: Environ Earth Sci, 2021, 646,1-10.

[18] Paterson, R. R. M.; Lima, N. Climate change affecting oil palm agronomy, and oil palm cultivation increasing climate change, require amelioration. Ecol. Evol. 2018, 8, 452-461.

[19] Dislich, C.; Keyel, A. C.; Salecker, J.; Kisel, Y.; Meyer, K. M.; Auliya, M.; Barnes, A. D.; Corre, M. D.; Darras, K.; Faust, H.; Hess, B.; Klasen, S.; Knohl, A.; Kreft, H.; Meijide, A.; Nurdiansyah, F.; Otten, F.; Pe, G.; Steinebach, S., ... Wiegand, K. A review of the ecosystem functions in oil palm plantations , using forests as a reference system, Biol. 2017, 49, 1539-1569.

[20] Paterson, R. R. M.; Lima, N. Climate change affecting oil palm agronomy, and oil palm cultivation increasing climate change, require amelioration. Ecol. Evol. 2018, 8, 452-461

[21] Paterson, R. R. M.; Lima, N. Climate change affecting oil palm agronomy, and oil palm cultivation increasing climate change, require amelioration. Ecol. Evol. 2018, 8, 452-461

[22] Chen, C.C.; McCarl, B. A.; Schimmelpfennig, D. E. Yield Variability As Influenced By Climate. Clim. Change, 2004, 66, $239-261$.

[23] Corley, R.H.V.; Tinker, P.B.H. The Oil Palm, 5th ed.; Wiley-Blackwell, Hoboken, New Jersey, USA, 2015; pp.1-680.

[24] Lobell, D. B.; Field, C. B.; Cahill, K. N.; Bonfils, C. Impacts of future climate change on California perennial crop yields: Model projections with climate and crop uncertainties. Agric. For. Meteorol. 2006, 141, 208-218.

[25] Ghini, R.; Bettiol, W.; Hamada, E. Diseases in tropical and plantation crops as affected by climate changes: Current knowledge and perspectives. Plant Pathology, 2011, 60, 122-132.

[26] Paterson, R. R. M. Oil palm survival under climate change in Malaysia with future basal stem rot assessments. For. Pathol. 2020, 50, $1-8$.

[27] Ambar Suharyanti, N.; Mizuno, K.; Sodri, A. The effect of water deficit on inflorescence period at palm oil productivity on peatland. E3S Web of Conferences, 2020, 211, 2-11.

[28] Kukal, M. S.; Irmak, S. Climate-Driven Crop Yield and Yield Variability and Climate Change Impacts on the U.S. Great Plains Agricultural Production. Sci. Rep. 2018, 8, 1-18. 
[29] Sarkar, M. S. K.; Begum, R. A.; Pereira, J. J. Impacts of climate change on oil palm production in Malaysia. Environ. Sci. Pollut. Res. 2020, 27, 9760-9770.

[30] Shafiq, K.M. The effect of rainfall distribution to production of oil palm in different location. Completed. Universiti Teknologi Mara, Malaysia. 2017.

[31] Munévar, F. Criterios agroecológicos útiles en la selección de tierras para nuevas siembras de palma de aceite en Colombia. Revista Palmas, 2004, 25, 148-159.

[32] Arshad, A.M., Armanto, M.E. \& Zain, A.M. Evaluation of Climate Suitability for Oil Palm (Elaeis guineensis Jacq.) Cultivation. J. Environ. Sci. Eng. 2012, (2B) 1 272-6.

[33] Corley, R.H.V.; Tinker, P.B.H. The Oil Palm, 5th ed.; Wiley-Blackwell, Hoboken, New Jersey, USA, 2015; pp.1-680.

[34] Pirker, J.; Mosnier, A.; Kraxner, F.; Havlík, P.; Obersteiner, M. What are the limits to oil palm expansion? Glob. Environ. Change. 2016, 40, 73-81.

[35] Pirker, J.; Mosnier, A.; Kraxner, F.; Havlík, P.; Obersteiner, M. What are the limits to oil palm expansion? Glob. Environ. Change. 2016, 40, 73-81.

[36] Fleiss, S.; Hill, J.K.; Mcclean, C.; Lucey, J.M.; Reynolds, G. Potential impacts of climate change on oil palm cultivation: A sciencefor-policy. Available online at: http://www.sensorproject.net/wp-content/uploads/2018/01/Climate-change-report-FINAL.pdf. (accessed 27 December 2020).

[37] Caliman, J.P.; Southworth, A. Effect of drought and haze on the performance of oil palm. Commodity of the Past, Tody, and the Future, International Oil Palm Conference, Sheraton Nusa Indah Hotel Bali, 23-25 September 1998. Indonesian Oil Palm Research Institute, Jl. Brigjend Katamso No.51, Kp. Baru, Kec. Medan Maimun, Kota Medan, Sumatera Utara 20158, Indonesia.

[38] Suharyanti, N.A., Mizuno, K., Sodri, A. The effect of water deficit on inflorescence period at palm oil productivity on peatland. The

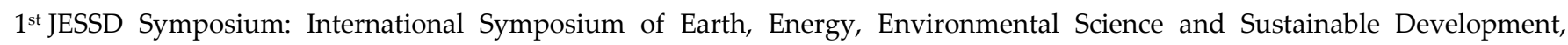
Universitas Indonesia, Indonesia, 20-28 September, 2020, E3S Web of Conferences, 17, Avenue du Hoggar, France.

[39] Corley, R.H.V.; Tinker, P.B.H. The Oil Palm, 5th ed.; Wiley-Blackwell, Hoboken, New Jersey, USA, 2015; pp.1-680.

[40] Sarkar, M. S. K.; Begum, R. A.; Pereira, J. J. Impacts of climate change on oil palm production in Malaysia. Environ. Sci. Pollut. Res. 2020, 27, 9760-9770.

[41] Fleiss, S.; Hill, J.K.; Mcclean, C.; Lucey, J.M.; Reynolds G. Potential impacts of climate change on oil palm cultivation: A science-forpolicy. Available online at: http://www.sensorproject.net/wp-content/uploads/2018/01/Climate-change-report-FINAL.pdf. (accessed 27 December 2020).

[42] Shanmuganathan, S.; Narayanan, A; Mohamed, M.; Ibrahim, R.; Khalid, H. A hybrid approach to modelling the climate change effects on Malaysia's oil palm yield at the regional scale. Adv. Intell. Syst. Comput. 2014, 287: 335-346.

[43] Paterson, R. R. M.; Lima, N. Climate change affecting oil palm agronomy, and oil palm cultivation increasing climate change, require amelioration. Ecol. Evol. 2018, 8, 452-461

[44] Hilal, Y. Y.; Ishak, W.; Yahya, A.; Asha'ari, Z. H. Development of genetic algorithm for optimization of yield models in oil palm production. Chilean Journal of Agricultural Research, 2018, 78, 228-237.

[45] Keong, Y. K.; Keng, W. M. Statistical Modeling of Weather-based Yield Forecasting for Young Mature Oil Palm. APCBEE Procedia, 2012, 4, 58-65.

[46] Keong, Y. K.; Keng, W. M. Statistical Modeling of Weather-based Yield Forecasting for Young Mature Oil Palm. APCBEE Procedia, 2012, 4, 58-65.

[47] Dufrene, E.; Ochs, R.; Saugier, B. Oil palm photosynthesis and productivity linked to climatic factors. Oleagineux, 1990, 45, 345-353. 
[48] Sheil, D.; Casson, A.; Meijaard, E.; van Nordwijk, M.; Gaskell, J.; Sunderland-Groves, J.; Wertz, K.; Kanninen, M. The impacts and opportunities of oil palm in Southeast Asia: What do we know and what do we need to know? Occasional paper, 2009, 51. CIFOR, Bogor, Indonesia.

[49] Legros, S.; Mialet-Serra, I.; Caliman, J. P.; Siregar, F. A.; Clément-Vidal, A.; Dingkuhn, M. Phenology and growth adjustments of oil palm (Elaeis guineensis) to photoperiod and climate variability. Ann. Bot. 2009, 104, 1171-1182.

[50] MPOB. Review of the Malaysian oil palm industry. Malaysian Palm Oil Board (MPOB), Kelana Jaya

Selangor, Malaysia. Available online at http://bepi.mpob.gov.my/index.php/en/ (accessed 28 July 2021).

[51] Hilal, Y. Y.; Ishak, W.; Yahya, A.; Asha'ari, Z. H. Development of genetic algorithm for optimization of yield models in oil palm production. Chilean Journal of Agricultural Research, 2018, 78, 228-237.

[52] Wong, C.; Uhlenbrook, S.; Zhou, Y. Variability of rainfall in Peninsular Malaysia. Hydrol. Earth Syst. Sci. Discuss. 2009, 6, 5471-5503.

[53] Wong, C. L.; Liew, J.; Yusop, Z.; Ismail, T.,;Venneker, R.; Uhlenbrook, S. Rainfall characteristics and regionalization in Peninsular Malaysia based on a high resolution gridded data set. Water, 2016, 8, 1-16.

[54]Muhammad, N. S.; Abdullah, J.; Julien, P. Y. Characteristics of Rainfall in Peninsular Malaysia. J. Phys. Conf. Ser., 2020, 1529, 1-13.

[55] Jirakiattikul, S.; Lan, T. T.; Techato, K. Advancing households' sustainable energy through gender attitudes towards rooftop pv installations: A case of the central highlands, vietnam. Sustainability,2021, 13, 1-15.

[56] Shafiq, K.M. The effect of rainfall distribution to production of oil palm in different location. Completed. Universiti Teknologi Mara, Malaysia. 2017. 